AperTO - Archivio Istituzionale Open Access dell'Università di Torino

\title{
Inflammation: An all-season phenomenon in human pathology
}

\section{This is the author's manuscript}

Original Citation:

\section{Availability:}

This version is available http://hdl.handle.net/2318/1759605

since 2020-10-25T08:17:01Z

Published version:

DOI:10.23736/S0393-3660.20.04349-1

Terms of use:

Open Access

Anyone can freely access the full text of works made available as "Open Access". Works made available under a Creative Commons license can be used according to the terms and conditions of said license. Use of all other works requires consent of the right holder (author or publisher) if not exempted from copyright protection by the applicable law. 


\section{Inflammation: An all-season phenomenon in human pathology}

Journal: Gazzetta Medica Italiana - Archivio per le Scienze Mediche

Paper code: Gazz Med Ital - Arch Sci Med-4349

Submission date: February 11, 2020

Article type: Editorial

Files:

1. Manuscript

Version: 2

Description: manoscritto

File format: application/msword 


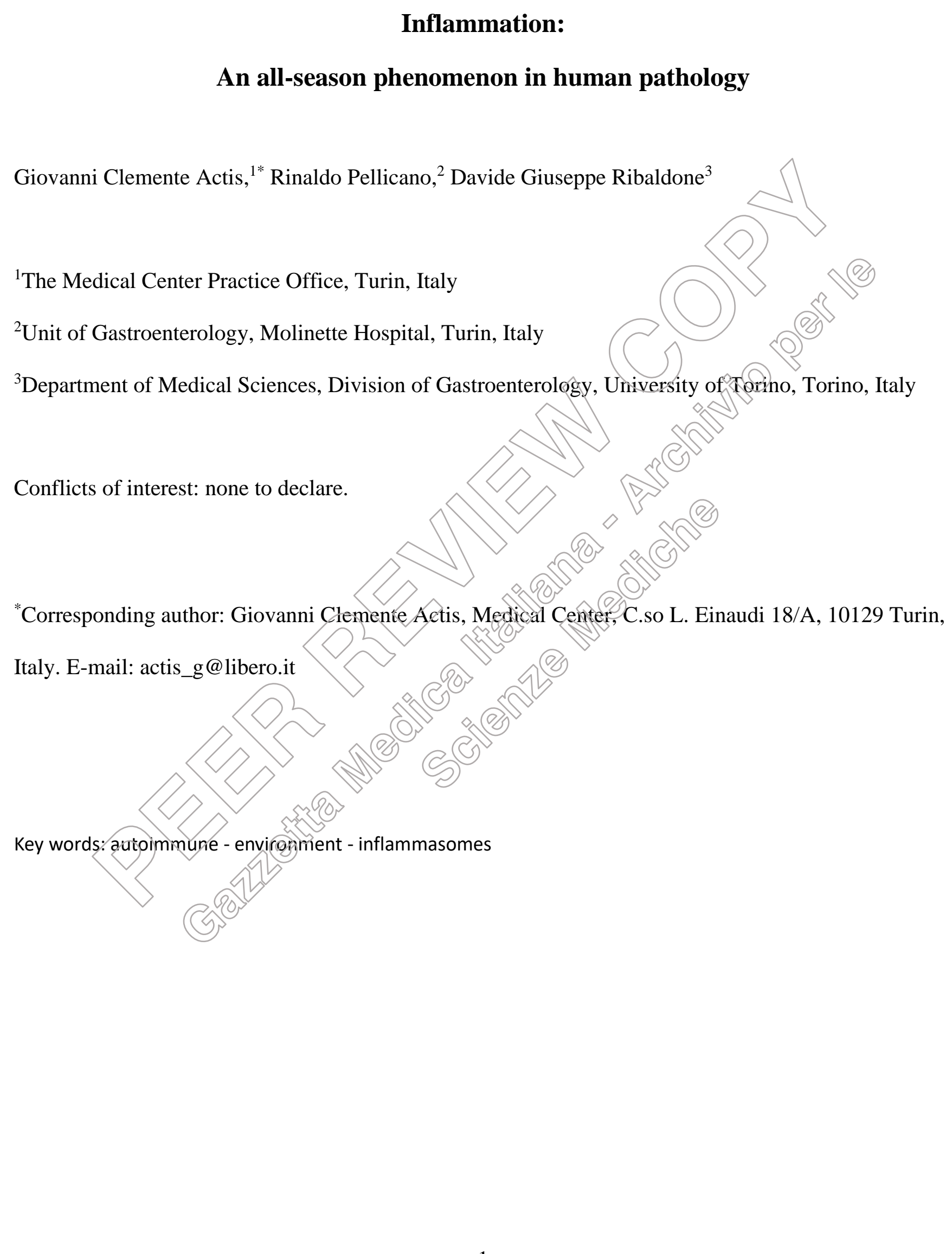


The interest of the scientific community on inflammation has been growing steadily, recently favoring the comprehensive perception of inflammation as a sort of nature's generalized way to cope with the environment. ${ }^{1}$ With a group of scientists, we have begun a translational analysis of the evolutionarily conserved process of inflammation. As a result of this work we have elaborated a "Turin concept" of inflammation as an evolutionary and pathologic drift. We have become interested in inflammation because of two main aspects. We first made the point that the clinical presentations (originally comprising the so-called cardinal signs of redness, sweiling, and pain) by the end of the $2^{\text {nd }}$ World War have left, as the legacy, a creeping form ${ }^{2}$ made of mildy relapsing fever, weakness, and elevated C-reactive protein, somewhat matching the contemporary overgrowth of "autoimmune" affections of a rheumatologic interest. ${ }^{3}$ Today, Western Societies arebeing plagued with such disorders, making important socio-economic issues. On this line, the appreciation of acute/chronic inflammation as an evolutionary carver of life has become of age. ${ }^{4}$ Sedoridly, inflammatory markers have now been found in unsuspected areas including neuropsychiary. In this case, patient's loss of the acquaintances with the outer world is paralleled by inflamanation marking the malaise at the organic level. Notably, inflammation is accredited with both arengic andicurrent negative effects on the central nervous system (CNS). Our ancestors experienced historical phases of cerebral weight loss contextually to waves of inflammation, ${ }^{6}$ whereas mgdern psychiatrists do reckon that inflamed psychiatric individuals are likely to be resistant to standard anti-psychiatric drugs. ${ }^{7}$ At the gut level, inflammatory signals cannot be ignored, in view of the crucial role played by the immune system in a barrier organ such as the gut. ${ }^{8}$ Examples of these statements might be the puzzling role of the inflammatory post prandial reactions, ${ }^{9}$ the double-sword work of the inflammasomes, ${ }^{10}$ and the patrolling action of the sub epithelial lymphocytes. ${ }^{11}$ On these stages, inflammation is surprisingly being revealed to swing between overt reaction (potentially a host tissue damage) and smart tolerance (protecting host). ${ }^{12}$ Moreover, one can only be fascinated by the evidence that the gut immune system is functionally correlated with the 
airway lymphocyte circuits ${ }^{13}$ through the effects of the still largely unknown microbiome. Wrapping up the notes collected above, one can see inflammation as a universally "magmatic" drift: from time to time permissive conditions may favor its materialization to defined clinical conditions and peculiar consequences. Parodontitis, ${ }^{14}$ and, intriguingly enough, Helicobacter pylori infection,, 5 might originate 10

Finally, we are just at the beginning of the road towards the implication of certain inflammatory markers as spies of our life expectancy. The intellectuat icon of inflammation is now steadily approaching that of a gear mediating the tyo-way directed dialogue between the individual and the surrounding.

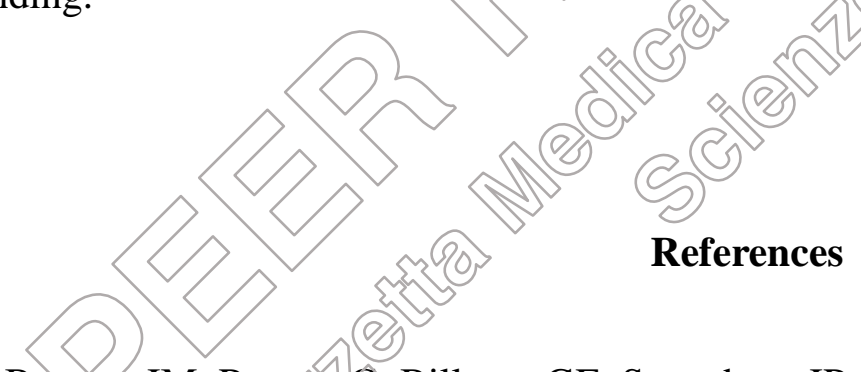

1. Bennett JM, Reeves G, Billman GE, Sturmberg JP. Inflammation - nature's way to efficiently respond to a1y pes of challenges: implications for understanding and managing "the epidemic" of chronic diseases. Front Med 2018;5:316.

2. Franceschi C, Campisi J. Chronic inflammation (Inflammaging) and its potential contribution to age-associated diseases. J Gerontol A Biol Sci Med Sci 2014;69(Suppl 1):S4-9.

3. Aller MA, Arias N, Fuentes Julian S, Blazquez-Martinez A, Arqudo S, Miguel MP, et al. Coupling inflammation with evo-devo. Med Hypotheses 2012;78:721-31. 
4. Actis GC, Pellicano R. Chronic (inflammatory) diseases: precision medicine versus comprehensive understanding? Minerva Med. 2018;109:150-1.

5. Khandaker GM, Dantzer R, Jones PB. Immunopsychiatry, important facts. Psychological Medicine 2017;47:2229-37.

6. Pruimboom L, Raison CL, Muskiet FA. Physical activity protects the haman brain against metabolic stress induced by a postprandial and chronic inflammation Behay Neurồ 2015; 2015:569869.

7. Mondelli V, Ciufolini S, Belvederi Murri M, Bonaccorso D, Di Forti M, Giordano A, et al. Cortisol and inflammatory biomarkers predict poor treatment response in first episode psychosis. Schizophrenia Bulletin 2015;41. 1162-70.

8. Branca JJV, Gulisano M, Nicoletti C. Intestinal epithelial barrier function in ageing. Ageing Res Rev 2019;54:100938.

9. Dror E, Dalmas E, Meier DT, Wueest S, Thevenet J Thienel C, et al. Post prandial macrophagederived IL-1beta stimulates insulin, and both syergistically promote glucose disposal and inflammation. Nat Immunol 2019:18:283-9,2.

10. Xue Y, Enosi Tuipulotu DoTan WH, Kay C, Man SM. Emerging activators and regulators of inflammasones and pyro-ptosis. Trends Immunol 2019;40:1035-52.

11. Lan RY, Mackay Hershwin ME. Regulatory T-cells in the prevention of mucosal inflammatory diseases: patrolling the borders. J Autoimmun 2007;29:272-80.

12. McCarville JL, Ayres JS. Disease tolerance: concept and mechanism. Curr Opin Immunol 2018;50:88-93.

13. Loverdos K, Bellos G, Kokolatou L, Vasileiadis I, Giamarellos E, Pecchiari M, et al. Lung microbiome in asthma: current perspectives. J Clin Med 2019;8(11):Pii E1967. 
14. Kaur T, Uppoor A, Naik D. Parkinson's disease and periodontitis - the missing link?

Gerodontology 2016;33:434-8.

15. Actis GC. Helicobacter pylori infection and Parkinson's disease. Min Gastroenterol Dietol 2019;65:164-5.

16. Ribaldone DG, Pellicano R, Actis GC. The gut and the inflammatory bowel diseases inside-out: extra intestinal manifestations. Min Gastroenterol Dietol 2019; 65:309-18.

17. Caviglia GP, Rosso C, Ribaldone DG, Dughera F, Fagoonee S, Astegiano M, Reiricano R. Physiopathology of intestinal barrier and the role of zonulin. Minerva Biorecnol 2019;31:83-92. 